$1-1-1996$

\title{
Of Vulcans and Values: Judicial Decision-Making and Implications for Judicial Education
}

Paul Biderman

University of New Mexico - School of Law

Follow this and additional works at: https://digitalrepository.unm.edu/law_facultyscholarship

Part of the Law Commons

\section{Recommended Citation}

Paul Biderman, Of Vulcans and Values: Judicial Decision-Making and Implications for Judicial Education, 47 National Council of Juvenile and Family Court Judges 61 (1996).

Available at: https://digitalrepository.unm.edu/law_facultyscholarship/154

This Article is brought to you for free and open access by the UNM School of Law at UNM Digital Repository. It has been accepted for inclusion in Faculty Scholarship by an authorized administrator of UNM Digital Repository. For more information, please contact amywinter@unm.edu, Isloane@salud.unm.edu,sarahrk@unm.edu.

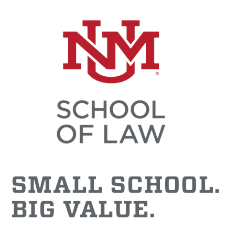

BIG VALUE. 


\section{Of Vulcans and Values: Judicial Decision-Making and Implications for Judicial Education}

By Paul L. Biderman, Esq.

\section{Introduction}

"The life of the law has not been logic; it has been experience." These seminal words of Justice Olıver Wendell Holmes have set the tone for much of modern jurisprudence, yet remain cryptic and elusive. What role does experience play in the development of the law? What kinds of expersence, and whose, may validly influence the development of the law? What constraints does logic impose on the judicial process? What are the proper roles of judges and legislators respectively in the development of the law" What is meant by the "life of the law," anyway? And when drawing upon experience in the application of the law, how does a judge avoid crossing the line of propriety into rank impulsivity or favoritısm?

Among the many difficult tasks that jurists must undertake, none may be more perplexing than that of reconciling their experience, as aggregated and reflected in their personal values, with their judicial duties. Not only are individual issues hard to resolve, but little in jurisprudence offers much of a framework within which even to approach the problem. Society and its legal practitioners send contradictory messages. The constitutional separa- tion of powers doctrine insists that law is created to effectuate policies valued by the legislatıve rather than the judicial branch. Yet judges know that they are called upon constantly to give meaning to general policies in specific cases, to weigh competing policies, and to develop new ones to address unantic:pated situations. One side calls upon the conscience of the judge to "temper justice with mercy;" while the other calls for a display of judicial iron through the aphorism, "hard cases make bad law." Of course, the same lawyer can comfortably send either message depending upon the strengths of the case and the interests of the client. For the judge, constant Identification with one approach to decision making can cast doubt on her impartiality; while excessive inconsistency may be derided as weakness of mind or will. Thus the judge is faced daily with the question of when she may appropriately incorporate her personal values in her decisions, and under what conditions and constraints she may do so.

Although writers on the legal process during the twentieth century have been far from unanimous, those who have explored this subject have generally acknowledged, explicitly or implicitly, at least some role for the judge's

Paul L. Biderman has since 1991 served as director of the Rozier E. Sanchez Judicial Education Center at the Instutute of Public Lav Univer sity of New Mexico School of waw. He gradusted untb a bachelor's degree in Political Science from the City College of New York in 1967 and attained his J.D. from New York University School of Law in 1970 . He moved 20 New Mexico in 1970 whth his wife, Ellen to work for three years as a legal services lawyer on the Navajo Indian Reservation. He was admitted to the New Mexuco State Bar in 1971.

Since moving to New Mexico he has served as an assistant and deputy attorney general in consumer protection and utility regulatson; served four years as the seate's Secretary ofEnergy and Minerals, and spent a total of seven years in private law pracuce. He also developed and taught a course in consumer law for the Unversity of New Mexico School of Law He and Ellen have two grown sons and make their home un Santa Fe. 
personal values in the work of issuing dectsions. At one extreme are those who seek the most legally deterministic system possible, excluding the judge's values from all but a few cases. At the other pole are those who argue that the judge's personal values really control every decision, rendering appeals to logic and precedent little more than window dressing to sell the masses on the myth of an objective legal system.

The hardest (if some of the least recognized) work, however, has been done by those trying to identıfy the places where the legal system actually invokes the values of its judicial officials, and to offer those officials guidelines for doing so. Ideal guidelines for applying values would protect the judicial process against accusations of arbitrariness; allow litıgants to draw freely upon and benefit from the informed instincts of a generally experienced, well-educated and sincerely disinterested authority; and would provide the judge comfort and confidence that the inevitable "gut decisions" need not be furtive exercises. Moreover, accepted guidelines would acknowledge and clarify the proper role of the judge's values in decision making. This would provide an important context for judicial education programs exploring and helping to develop those values.

This article will begin by analyzing the writungs on this issue by a sampling of legal scholars dunng this century, showing how each viewed the role of personal values in the work of the judiciary. I will then attempt to identify where values clearly or arguably enter decisions, not because judges necessarily want them to but because the legal system compels it. In particular, I will explore that role not only in the more visible context of monumental appellate decisions, but also in the seemingly routine actions of every judge who sits on a bench. I will then review some guidelines that have been offered for appropriate application of values in the judicial process. The article will conclude by suggesting ways in which judicial education programming can assist judges as they prepare to exercise their responsibility to apply their values farrly and wisely.

\section{A Survey of Legal Writers}

\section{A. Justice Holmes Breaks the Determinust Ice}

It is inevitable that the work of Justice Oliver Wendell Holmes should provide the starting point for this inquiry. Holmes' powerful mind and prose left an irreparable fault line in the false granite of legal determinism. He established high and enduring hurdles for those who would argue for "nght answers" to legal problems.

Holmes described as dangerous "the notion that a given [legal] system, ours, for instance, can be worked out like mathematıcs from some general axioms of conduct. Judicial dissent is often blamed, as if it meant simply that one side or the other were not doing their sums right, and, if they would only take more trouble, agreement inevitably would come." For Holmes,

"The life of the law has not been logic; it has been experience. The felt necessities of the time, the prevalent moral and political theories, intuitions of public policy, avowed or unconscious, even the prejudices which judges share with their fellowmen, have had a good deal more to do than the syllogism in determining the rules by which men should be governed. The law embodies the story of a nation's development through many centuries, and it cannot be dealt with as if it contained only axioms and corollaries of a book of mathematics."2

While he sympathized with the desire of the human mind to find logical certainty in legal conclusions, he denied the possibility of doing so in many cases, even despite his own formidable logical and rhetoncal skill. "Behind the logical form lies a judgment as to the relative worth and importance of competıng legislative grounds, often an inarticulate and unconscious judgment, it is true, and yet the very root and nerve of the whole proceeding."3 These judgments he described as beliefs and attıtudes, subjective in nature and temporal in duration. "We do not realize how large a part of our law is open to reconsideration upon a slight change 
in the habit of the public mind."

It might seem curious that a social conservative, the scion of a patrician New England family, would have emerged as the source of a doctrine that threatened the foundation of objectivity upon which the courts of his time had premised their authonty. He was certainly aware that the judiciary had been called upon to preserve the interests of the wealthy against reformist, if not socialist, political movements, yet he repeatedly rejected that invitation. ${ }^{5,6}$ One may theorize that his own experience in life had somehow left its indelible, if silent mark: as a young officer in the Union Army, he had received serious wounds in three Civil War battles.' Putting aside these speculations, his writıngs appear aimed toward protection of the integrity of the legal system agaunst the charge of conscious or unconscious service to particular interests. Only by acknowledging the real process behind the facade of objectivity could the judiciary retain, on its own terms, the public respect critical to the operation of our legal system.

However influential his broad pronouncements, Holmes left to future authors the tasks of filling in such details as identıfying the point where logic may properly give way to values; defining limits on the values upon which the judge may draw; and directıng judges toward the sources and contents of values fundamental to our system of laws. It is tasks like these to which we shall proceed.

\section{B. Indeterminate Posttivism}

At first glance, posituvism might seem to be the last philosophy to tolerate judges' drawing on their values for solutions to legal problems. H.L.A. Hart, the most prominent spokesperson for positivism in this century, argued that law must be distınguished from morals. The law, in expressing the sovereign authority of the state, tells us what is; it provides rules that govern our actions and relations. To ask what should be, we must turn not to the law, but to morality. So long as the authority promulgating the laws satisfied certain secondary rules of legitimacy, its primary rules governing specific behavior would be effective. Under this construct, the primary obligation of the judge is to apply the law of the sovereign and certainly not to bend the law to serve social purposes that might comport with the judge's values.

In fact, however, this philosophy was quick to acknowledge the role of the judge's values in decision making. In his foremost article on the subject, Hart recognized the existence of "penumbral" legal problems that cannot be solved by statutory words or deductive reasoning alone." In such "interstitial" cases, judges must attempt to draw out the policy of the laws from the statutory language. While this should be viewed as an elaboration of the rule itself rather than as the preference of any individual, nevertheless Hart acknowledged, "Surely it cannot be doubted that, for most cases of interpretation, the language of choice between alternatıves, 'Judicial legislation,' or even 'fiat,' (though not arbitrary fiat) better conveys the reality of the situation. [W] live among uncertainties between which we have to choose, and the existing law imposes only limits on our choice and not the choice itself."

Hart subsequently modified his position by clarifying that judges do not simply legislate from thin aur for such interstitial cases, but rather work by analogy to accepted legal principles. ${ }^{10}$ He nevertheless stood by the position that judicial lawmaking is inevitable,

“ since in any hard case different principles supporting competing analogies may present themselves and the judge will have to choose between them, relyıng like a conscientious legislator on his sense of what is best and not on any already established order of priorities among principles already prescribed for him by the law." "I

Much the same sentument was expressed by former California Supreme Court Chief Justıce Roger Traynor, who warned against being "misled by the half-truth that policy is a matter for legislators to decide. Recurringly it is also for the courts to decide," in areas not covered by the legislative enactments. ${ }^{12}$

While many legal matters are subject to clear resolution by applying legislative standards, such matters are often disposed of well before they reach litigation. Thus Hart's positiv- 
ism clearly acknowledges a critical role for the judge's values in at least one important class of cases: those where neither the language of the law nor the powers of deduction provide a clear statement of the outcome.

\section{A Dash of Realism}

Where the positivists found in the interstices of the law a niche for the judges' values, the legal realists found a gaping canyon. In terms that sometımes tumed cynical, the realists like Jerome Frank derided the myth of judicial objectivity and attributed virtually all judicial decisions to personal values:

"The robe gives the impression of
uniformity in the decisions of the priestly
tribe. Says the uniform black garment
to the public mind: judges attan their
wisdom from a single, superhuman
source; their individual attitudes never
have any effect on what they decide.
Patently, that belief is delusional."13

Frank described a decisional process wherein the judge begins with a "hunch" about each case, a "composite reaction of a multitude of responses to the stimuli set up by witnesses -- stimuli which encounter the judge's biases, 'stereotypes,' preconceptions and the like. On all this, formal law is silent."' The judge's references to logic and rules of law in the opinion are merely designed to create an "appearance" of objectivity." Starting from this theme, the realists concluded that judges needed to reject charades of formalistic decision making deriving from objectıve legal principles, and openly incorporate current social and political realities into their analyses. ${ }^{16}$

Critics of the realists included Roscoe Pound, who had written earlier to emphasize the importance of the scientific component of the law, "to eliminate so far as may be the personal equation in judicial administration, to preclude corruption and to limit the dangerous possibilities of magisterial ınorance."17 Despite such wamings, however, Pound, too, called for the introduction of sociological information into the legal system, to substitute "the human factor" for formalistic application of abstract legal principles. ${ }^{18}$ As elaborated by
Benjamin Cardozo.

"The final cause of the law is the welfare of society Logic and history and custom have their place. We will shape the law to conform to them when we may; but only within bounds. The end which the law serves will domınate them all."19

Although Cardozo maintained that "[a] judge is to give effect in general not to his own scale of values, but to the scale of values [especially legislative pronouncements] revealed to him in his readings of the social mind," 20 he nevertheless saw the inevitability of ambiguous situations leaving the judge without adequate guidance:

"At those times, he must put himself as best he can within the heart and mind of others, and frame his estımate of values by the truth as thus revealed. Objective tests may fail him, or may be so confused as to bewilder. He must then look within himself."21

Somewhat more recently, Dennis Lloyd expounded on the legal realist approach. He maintained with the realists that "Judges, like other human beings, cannot divorce themselves from the pattem of values which is implicit in the society or the group to which they belong, and no amount of consciously applied impartıality or judicsal lack of passion will succeed in eliminating the influence of factors of this kınd."2 Lloyd did temper his analysis with the recognition that reasoning and precedent provide direction to the judicial process. Nevertheless, he still saw the necessity of making value judgments as to the desirability of var1ous consequences of applying precedents to new fact situations.
" [L]egal decisions are inevitably based on an ideology. It is better to face up to this and make a conscious effort to recognize what are the opera- tive values of one's society and develop the law accordingly, rather than attempt to treat all legal decisions as purely technical exercises in legal logic."23

The realists permanently unclothed the myth of judicial objectıvity, but subsequent writers 
have shown where they overstated their case. One need not subscribe to the notion that all decision making derives from judges' personal values to recognize that such values play a significant role in conjunction with other factors. The challenge is to identify where the balance among all these factors is to be struck.

\section{Seeking the Right Answer}

\section{The strong approach}

\section{Wechsler's neutral principles}

The legal writers discussed thus far have all agreed that judges' values enter into their decisions, although they have differed over when, how and how much. There have been an opposing group of modern legal philosophers, however, who would allow little or no room for the personal philosophy of the judge in his decisions. Ironically, two of the most prominent of these would disagree strenuously with each other over the nature of the judicial process and even more vehemently over the direction the law should take. Despite these differences, they share a general belief that the judiciary can and should find "correct" answers to most if not all legal problems, so they appear in the same section of this article. And both, in very constrained but unmistakable ways, im. plicitly acknowledge a role for the judge's values.

For Herbert Wechsler, the right answers lay in judicial reliance on neutral principles of law, at least for constitutional interpretation. ${ }^{24}$ Wechsler attacked what he viewed as ad hoc declarations of constitutional nights that are not based upon principles transcending the case at hand. Absent such neutral principles, the courts should restrain themselves from second-guessing the value judgments of the other branches of the federal government or of the states. Wechsler found such principle lacking in a number of important Supreme Court rulings, including even Brown v. Board of Education. ${ }^{2 s}$

Despite his strong advocacy of restraint toward value-based action by the judicial branch, Wechsler still seemed at least to articulate a position that renders such action all but inevitable. In sharp contrast to those on the current Supreme Court who would reject almost any attempt to exceed the intent of the framers of the Constitution, Wechsler acknowledged that the Bill of Rights is a living document that must be interpreted in light of modem conditions. Distınguishing the due process and equal protection clauses from the original provisions of the Bill of Rights, he said.

"I argue that we should prefer to see the other [original] clauses of the Bill of Rights read as an affirmation of the special values they embody rather than as statements of a finite rule of law, its limits fixed by the consensus of a century long past, with problems very different from our own. To read them in the former way is to leave room for adaptation and adjustment if and when competıng values, also having constitutional dimension, enter on the scene."26

Wechsler qualifies this statement by insisting that in taking this kind of action, the courts must act in a manner that is "entirely principled."27 He would not have acknowledged that the judges' own values may enter into constitutional development. The difficulty with his position, however, is that value choices are inherent in such constitutional evolution if it is to mean anything. To take one of Wechsler's own examples, he agreed that the Fourth Amendment protections against unreasonable search and arrest are not limited to enshrining the common law protections that were in force when the amendment was adopted. But since he acknowledged that those protections may be extended to address modern day "police problems," and since he also acknowledged that the responsibility for extending such protections lies with the courts, how can judges avoid interpolating their own values into their actions?

Ultimately, when it comes to weighing society's interest in protection by police against its interest in protection from police, it is left to judges who are human beings -- as well-informed, well-trained, impartial and disinterested as they may be -- 10 make that call. Judges are often presented with two or more viable interpretations as to the lawfulness of a particular search, in an all but infinite variety of 
factual situations. These judges must ult1mately decide whether the value to society of encouraging searches that help the police uncover or prevent crimes outweighs the value of protecting citizens agannst searches by police who lack adequate grounds for suspicion. Both alternatıves have value -- as well as legal support -- in any given case; but there simply is no objective, foolproof way of determining which has more. Neutral principles may be discovered that can impose limits on the questions that judges can address, and perhaps they can constrain them to a narrow list of acceptable choices. But choices among values often remain, and neutral principles cannot displace the judge's search through her own value system to determine which shall prevail.

\section{Dworkın's "Law as Integrity"}

Thus, I contend, Wechsler's position unwittungly necessitated that judges consult their own values. Far more conscious of this issue, however, is Ronald Dworkin. Dworkin is undoubtedly the preeminent modern advocate for a judicial system that produces a "correct answer." He developed an elegant concept of "Integrity in Law" "2i

"According to law as integrity, propositions of law are true if they figure in or fall from the principles of justice, fairness and procedural due process that provide the best constructive interpretation of the community's legal pract1ce."2o

The hallmarks of law as integrity include consistency, coherency, and the "principled extension of past political decisions." 30 Dworkın acknowledges that there are hard decisions to be made, and judges make them by "trying to find, in some coherent set of principles about people's nghts and dutses, the best constructive interpretation of the political structure and legal doctrine of their community."31 He likens the duty of each judge to that of each successive author of a chain novel, who carries forward the style and substance of preceding authors as each chapter is added, ensuring the coherency of the whole. As Dworkin has put it more recently, "[ $[$ ] hey must regard themselves as partners with other officials; past and future, who together elaborate a coherent constitu- tronal morality, and they must take care to see that what they contribute fits with the rest." ${ }^{232}$

Thus Dworkin shares with Wechsler the commitment to principled decision making that is based on standards deriving from sources other than the judge's own moral sense. The judge does not select among competing values based on his own preferences, but rather on the fabric of justness, faimess and political morality that best reflects the morality of his community. He does so creatively, as he tries to build on past work to address new situations. Similarly, in interpreting constitutional rights, the judge must Identify and then carry forward the principles that underlie the entire structure of the provision and of the Constitution as a whole. It is not enough to know that the Equal Protection Clause sought to vitiate the impact of slavery; the underlying principle related to creating equality among the races. But judges' responsibility to recognize and effectuate underlying principles of law does not imply license to insert their own values into their decisions. "Law as integnty condemns activism, and any practice of constitutional adjudication close to it. It insists that justices enforce the constitution through interpretation, not fiat, meaning that their decisions must fit constitutional practice, not ignore it." ${ }^{33}$

Even despite this insistence on the attainability of a correct answer through such reasoning alone, Dworkin admits to a narrow range of decisions within which judges draw upon their own moral resources. Assuming a chosce between two approaches, one emphasizing justice and the other farmess, without clear guidance from precedent, the judge's choice "will depend not only on his beliefs about which of these principles is superior as a matter of abstract justice, but also about which should be followed, as a matter of political faimess, in a community whose members have the moral convictions his fellow citizens have." ent aspects or dimensions of a judge's workıng approach -- the dimensions of fit and substance, and of different aspects of substance -are in the last analysis all responsive to his political judgment." 35 In his more recent iteratıon, Dworkın has stated: "Very different, even 
contrary, conceptions of a constitutional principle will often fit language, precedent, and practice well enough to pass these tests [of history, practice and integrity], and thoughtful judges must then decide on their own which conception does most credit to the nation." ${ }^{36}$

Dworkın confines the judge's own value system to a very limited role under this construct of the legal process, but even in his system of correct answers to legal questions, that role exists. As pointed out by Cornelius $F$ Murphy in his critique of Dworkın's work, judging is more complicated than the relentless search for a singular value to ultimately guide every decision:

"When a legal controversy cannot be resolved by straightforward reference to prior law, it presents a complexity grounded upon a conflict of values.

To fairly resolve the dispute, the judge must address the opposition of values that lies at the heart of the litigation.

To exercise choice in these circumstances one must do more than seek coherence of prnciple. These "hard" cases test the personal resources of a judge because the direction of the decision cannot be known in advance." 37

Murphy points out that this indeterminate quality of difficult cases describes the range of discretıon available to judges; whereas Dworkın would attempt to apply a controlling scheme of values fundamental to a given society and limit the judge to a variety of interpretative strategies for realizing them. Dworkın has done much to help the judge in making difficult decissons by providing guidelines for one aspect of the judge's discretion; but he fails in his goal of eliminating altogether consideration of the judge's own values. Moreover, where values must be invoked to decide a difficult case, Dworkin would leave the judge reliant upon the values of the community, not her own values. We shall examine this claim in our consideration of the next author.

The gentle approach

3 Greenawalt: A Modest Claum for Determinacy
Where Wechsler and Dworkin, from largely opposing perspectives, find strong grounds for determınative answers to legal questions, Kent Greenawalt pursues what he characterizes as a modest claim of determinacy in law, the indicia of which are:

" that many legal questions have determinate answers that (1) would be arrived at by virtually all those with an understanding of the legal system, and (2) are unopposed by powerful arguments, consonant with the premises of the system, for contrary results." 38

Greenawalt reaches this conclusion after acknowledging that some cases are indeterminate. In particular, he notes the impossibility of establishing transcendent factual truths in law, because all facts are filtered through human consciousness, "and no one person's consciousness is exactly the same as another's." $39 \mathrm{He}$ maintains nevertheless that many legal questıons are subject to determınative answers based on the application of clear statutory, constitutional or common law standards. When these are not sufficiently clear to determine the law in a given case, then the judge must turn to the standards of the community for assistance. Only when both the letter of the law and the values of the community have failed to provide a determinative answer may the judge finally turn to her own values to decide the case. ${ }^{40}$

Yet Greenawalt himself perceives the difficulties in this rough schema. There are many areas in which the law gives discretion to judges. Sometımes this discretion is quite broad, but often it is circumscribed by some standards in the statutes and/or caselaw. Greenawalt implicitly acknowledges, however, that even the application of such standards can be subject to the values of the judge deciding the case. As an example, he cites the difficulties inherent in applying a "reasonable man" standard to certasn determinations, such as deciding that certain inflammatory language constitutes "fightıng words" that should be punished. The same words that might induce a "reasonable man" to fight might not so induce a reasonable woman, child, or elderly person. ${ }^{41}$ Whose value system does the judge apply in deciding whether the words would have in- 
duced a reasonable person to fight? The law provides no guidance outside the judge's own value system.

This acknowledgment by Greenawalt ${ }^{42}$ leads him to a much broader concern with his analysis, as well as that of Dworkın: if, when the law is not adequately determinative by itself, the judge is to rely upon the values of the community above her own values, how exactly is she to determine and weigh those community values? Assuming the judge acts in good faith (e.8., does not act from personal financial interest or from outright bigotry), then how does the judge determine the values of "the community" -- by conducting public opinion polls? Which community's values is the judge to follow in a multiethnic, multiracial society the community of her birth and upbringing; the community of the majority or the most influential; some consensus among the various minorities; or something else? If values differ in different settıngs, is the urban judge to rule inconsistently from the rural judge merely because the values of their communities differ, even if they personally agree? How is the judge even to ascertain accurately the relative importance of conflicting values within a given community, even if an appropriate one were selected? And even where community values are clear, what happens when they conflict in the individual case, as in the example of community support for restrictions on police searches versus its support for controls on crime? As Greenawalt aptly points out: " [E]ven in a culture in which many values are shared, sharp division may occur on certain subjects that are important for the law." 43 The complexities of settıng up a standard based on community values will be explored further in the next part of this article, but already it seems doubtful that community values alone can determine the outcome of the judicial decisions in cases where the law alone provides inadequate guidance.

Greenawalt himself recognizes this. ${ }^{14}$ While he invokes community standards to fill in guidance if possible where statutes are inadequate, he knows that community standards alone are often too inchoate to suffice. The law, as seen by Greenawalt, incorporates standards of reference to three still broader sources: cultural morality, political morality, and economic efficiency. ${ }^{\text {ss }}$ His point here is that the laws cannot anticipate every set of circumstances that will arise, so those who interpret and apply it must have some reference points in makıng those determinations. While this construct is a valuable contribution, it still cannot -- and does not purport to -- answer the question of how the judge selects among these broader sources when they point in conflicting directions.

Greenawalt concludes that there are often correct answers to legal questions deriving from cultural and political morality, but that for some questions there is "no legally relevant balance of reasons favoring one side." 46 In effect, Greenawalt expands on the search launched by Dworkin for sources outside the letter of the law upon which judges may draw in difficult cases. He finds such answers available in most, but not all cases, in his reliance on cultural and political morality and economic efficiency.

This approach finds support from the practicing bench in the writing of Judge Harry Edwards of the U.S. Court of Appeals for the District of Columbia Circuit. ${ }^{47}$ Edwards divides appellate cases into easy, hard and very hard. The latter category, comprising some 5 to $15 \%$ of the total caseload, are the only ones where no clear outcome can be determined from the law alone, and therefore require the judge to draw on social and moral beliefs. Edwards sees these cases, though difficult, as the stımulus to struggle toward princıpled bases for decision. Despite his commitment to make this effort, he nevertheless acknowledges:

"That such decision-makıng will inevtably be informed by our private social and moral beliefs need not mean that it will be marred by our private partisan agendas."

What I have difficulty discerning with clarity in this line of argument is the dividing line between the different types of cases, or any measure for the proportion of cases in each group. As I shall suggest below, the category of cases in which even the broader sources still fail to give determınatıve answers is quite large, necessitating the judge to draw upon her ultı- 
mate source of guidance, her own moral sense, with great frequency.

\section{E. Enter Deconstruction.}

Where Wechsler, Dworkın and others tried to undo the work of the legal realists by emphasizing the determinacy of the law, others have been seeking to carry legal realism still further through a complex of approaches loosely grouped as "critical legal studies (CLS)." Exploration of the range of CLS positions would exceed the scope of this article, but one of the perspectives they generally have in common is their belief that the legal system is constructed to appear neutral while in fact advancing the ends of certann powerful societal interests over other, weaker interests. Thus, this argument mantauns, judges who apply the principles of this legal system are in essence protecting the interests of the more powerful groups within society, whether or not they do so consciously. CLS is intolerant of claims for "neutral principles" and "determinative outcomes" to legal problems, preferring instead to view legal doctrines as malleable and intelligible only from a political perspectıve.

In these respects CLS has much in common with the legal realists. Where they part company (with regard to the subject of this essay), however, is in how to address the role that social policy plays in legal decisions. Where legal realists would explore and then strike a balance among the competing interests, CLS finds that impossible:

"In our society, the class of decisionmakers is not representative enough to provide the assurance the Realists wanted. Decision-makers are an elite, demographically unrepresentative and socialized into a set of beliefs about society and technology that skew the balance that they reach." 4

While this hardly scratches the surface of the varied body of thought represented by CLS, it is already clear that its proponents place a very high importance on the values of the individual judge in the decisions that she renders. Perhaps the only counter argument to that statement could lie in the idea that, if CLS theory is correct, then the imprint of powerful interests is so deeply embedded in the legal system that even a judge whose values firmly contradict those of the powerful would be unable to maneuver the legal system in her preferred direction. CLS, however, seems 100 committed to the concept of legal indeterm!nacy and contradiction to allow that escape. ${ }^{\text {so }}$ At most it can be said that in this view, the values advanced by the legal system play a greater role than those of the individual judge; but certanly not nearly to the point that the judge's hands are tied. Thus for our purposes, we can comfortably count CLS in the forefront of modern legal theories that find an important role for the values of the individual judge in her decision making activity.

\section{F In Pursult of Gutdelines}

Some authors have sought to develop guidelines to which judges may refer in deciding cases that are not completely determined by the rules of law. Their work is valuable both in Identıfying how the judge decides cases where values are at issue, and in establishing the factors that can lend legitımacy to such judicial determinations.

One such author is Thomas Morawetz. In his introductory work on legal philosophy, ${ }^{\text {s1 }}$ he helpfully reminds us that law is an artifact, a human creation, not a natural object that exists apart from any human intervention. As an artifact, the law is not something we discover so much as something that we continually create; and where we look for a right answer in the law for a given question, we are inherently limited by the fact that the law as developed to any one point may never have contemplated addressing that question. Sufficient observations and analysis of a natural object may eventually reveal generally accepted, scientifically verifiable truths about its properties; the correct answer to a legal question may not be determinable to the same degree of certainty no matter how long or thoroughly we study the applicable law. ${ }^{\mathbf{S 2}}$

Similarly, Steven J Burton exposes as "pretense" the notion that "legal rules, logically applied, dictate the results in all cases gov-

1996 / Juvenile \& Family Court Journal 69 
emed by the law."s3 Burton defines indeterminacy as a fixture in the law that occurs in a case:

" most notably when the law has incompatible implications for concrete judicial action and, on thorough analysis by impartial and capable lawyers, no standard or set of standards that generates a determınate result withın any practicable frame of reference."

In addition to this judicial indeterminacy, Burton also addresses the existence of discretion deliberately conferred on judges by the law.

Morawetz and Burton explore the nature and limits of the judge's discretion within a legal system that is thus subject to indetermlnacy, but is still not arbitrary. Burton develops guidelines aimed at ensuring that the judge exercises his discretionary power in good faith. According to Burton:

"The law can constrain the considerations upon which judicial action should be based by defining the set of all (legally) relevant reasons, guiding the judge without dictatıng a result."ss

Burton's argument is that although discretion devolves onto the judge either by design or circumstance, the law still neither leaves the judge free to do as he pleases, nor compels him to draw blindly upon extralegal sources for the answer. Instead, the law prescribes the accepted reasons upon which the judge may and may not draw. These acceptable reasons derive from the statutory text, legal principles implicit in the law, and other relevant standards. The discretionary function of the judge then comes down largely to weighing various considerations presented by the facts of the case, but considering only those reasons that are allowed by law. Excluded from such consideration would be ad hominem factors such as selfinterest of the judge; fraud; unjustifiable assertion of bald power; or racial, ethnic, gender or other prejudices.

Although Burton alludes both to limiting and authorizing standards governing the judicral exercise of discretion, he primarily emphasizes the constrants umposed by the law on the judge. If the judge observes those constraints, he may generally be said to be exercising his discretion in good faith. Morawetz recognizes that rules of law place limits on what a judge may consider in exercising discretion. Yet he is not satisfied by the.idea that law does so little. A parent or teacher who does not abuse her authority does the right thing, but may not, on that basis alone, lay claim to excellence in parenting or teaching. Similarly, just because a judge accepts the limits on her authority and does not violate them, does not alone mean that the judge has fulfilled her full potential to dispense justice, or even completely carried out all of her responsibilities. "There is need to complete a theory of justification by askıng what it would be desirable for a judge to do." 36

"The decisions of judges are not fully determined by rules. In hard cases, where the rules have open texture, judges will have recourse to princıples that represent values. Moreover, petitioners in hard cases will make claims by appealing to such values and citing such principles." "s?

Morawetz develops several mostly utilitarian princıples under which judges should act when deciding indeterminate cases. These principles include: (1) that the judge's decision is issued according to publicly shared standards; and (2) that the decision is designed to maximize the benefits for the litigants and the public. Among factors determining whether the latter principle is served are: (a) whether the judgment considers the interests of those, other than the petstioners before the court, who would have to modify their behavior as a result; (b) whether the judgment considers the indirect implications as well as the direct consequences of the decision; 0 whether the decision is consistent with other legal rules; (d) whether the judgment considers the consequences to those relying on the existing law.

David E. Van Zandt enters this discussion by injecting the concept of "common sense." Judges draw upon this faculty when they lack sufficient information about the case or guidance from the law. He defines the concept as the "collection of both moral and empirical information or theories about the world commonly held by individuals in a society" As a 
publicly available body of both empirical and normative information, common sense is distınguishable from the judge-centered faculties relied upon by Burton. But Van Zandt urges restraint in its use.

A very valuable analysis is offered by yet another author, Catharine Pierce Wells. ${ }^{60}$ Professor Wells demonstrates the inherently situated nature of judicial decision-making, the fact that every legal judgment is made from a particular perspectıve of the judge. She disproves logically any possibility that a judge can reason totally impersonally from a system of rules, by demonstrating that legal rules "require an active participant who can decide on each occasion whether the occasion is an appropriate one for applying a rule." ${ }^{1}$ Takıng a pragmatıc perspective, Wells calls upon judges to examine problems not only structurally -from the "outside in" -. by considening the problems in the context of the various legal theories that encircle them. Judges must also consider problems from the "inside out," empathizing and connecting with the various parties to see the issues from their perspectives. Neither approach can stand alone in effective judging.

These authors thus attempt to elucidate principles to help judges navigate the minefield of discretionary decision-making. It should be pointed out that for Burton, even when judges are weighing the competing values invoked by a difficult case, the judges are not -- or at least, should not be -- basing their decision on their personal values, which he views as "ad hominem" factors. While I disagree with his statement in so far as it denies a role for the judge's personal values, it is possible the difference is semantic. As will be explored below, a judge who must decide a case after weighing several competing values implicated in the case cannot avoid filtering that decision through her own value system. Burton himself debunks the notion that there could be some kind of numencal measure that would remove the judge's discretion from that picture. Yet, we must ask from where does the judge find the inspiration to weigh the competing values implicated by a case and lawfully subject to consideration? Ultımately, that judge has no al- temative but to decide which of those values is more important according to the judge's own experience and view of the world. As we shall see, that is the very kind of personal value judgment that our jurists are hired to make.

This survey of contemporary thinkers on the judicial process is certainly far from comprehensive. Other legal philosophies, such as the Law and Economics movement, may also have bearing on this question. ${ }^{63}$ What our survey has shown is that many, including some of the strongest legal determinists, have identsfied a role for the judges' personal values in their decision-making. Others have denied that role, but have without exception acknowledged the existence of difficult discretionary situations; situations, I contend, that inevitably require that the judge exercise her personal values. The next part of this article will attempt to define more precisely the role for the judge's values and the criteria for their responsible exercise.

\section{The Role of the Judges' Values in Judicial Decisions}

\section{A. Values in The Landmark Case}

For most students of the law, discussions of values in judicial decision-makıng immediately suggest the appellate case. In partıcular, thoughts tum to decisions of the U.S. Supreme Court and the cases that have represented milestones in the development of our jurisprudence.

\section{Brown v. Boand of Education}

I would guess that most informed people, whether lawyers or laymen, if asked to name a case where the judges drew upon their values to render a decision, would come up with Brown v. Board of Educallon. Several factors would certainly support their conclusion. The Coun that decided Brown overtumed established legal precedent, ${ }^{65}$ so the case could have been decided differently within the context of established law. Apart from simply deferring to the Congress or the states to act, the Court could have ordered the states to make the segregated schools serving black popula- 
thons equal to those serving whites. Indeed, the Court at that time had no civil rights statute or case law to rely upon in rendering its decision. Instead, the Court used its prerogative to interpret Constitutional provisions and found from sociological evidence that segregated schools are inherently unequal, hence unconstitutional. ${ }^{\circ 6}$ There can be no doubt that the members of the Warren Court viewed segregation in education as an intolerable blight on a democratic form of government. Why else would the unanimous Court, including even the advocates of judicial restraint led by Felix Frankfurter, have been willing to assume the lead in what was to become the most contentious social revolution of their time, the civil rights movement?

For the purposes of this article, it is important to note that it is not enough to claim that the Justices in Brown simply followed the values of the "community." Which communities" values were they following? Certainly not those of the white southern majority, as subsequent events bore out. ${ }^{67}$ Yet the decision was aimed at southern and other state schools where de jure segregation was ubiquitous. If the Justices chose to apply the values of the black minorities in those states, on what basis did they choose to do so, other than thear own preference for those values? Recall that the state of the law at the time would have allowed the Justices to adopt less decisive alternatives.

It could be argued that the Justices were applying the values not of the region in question, but of the nation as a whole. But how would they have known that? Even if segregation in public schools outside the south were the exception, that did not mean that the nation as a whole had decided to impose integrated schools on the portion of the country that remaned segregated. If it had so wished, Congress, which was comprised of mostly nonsoutherners, could have passed legislation to do so; it had not. Nor could the Justices have believed that racism agaunst blacks was limited to southerners; if discrimınation remained alive throughout the country in other forms, would the rest of the country really stand up to end segregation? The point is not to suggest that the Justıces necessarily considered these ques- tions; rather that, in deciding this case, the Justices had to choose among values held by communities with sharply disparate views. That they chose to end school segregation (at least in principle) was not a reflection of their decision to endorse the values of any particular community or segment thereof, but rather of their own (courageous) consciences and moral belief systems.

\section{Values in Current Cases}

While Brown poses a clear, and highly supportable, example of judges' interjection of their own values into their decisions, less momentous cases contınue to demonstrate the same phenomenon. As we look at two examples, it is important to remember that I am not simply claiming that this is what judges do; they may be doing the wrong thing. I am claiming that, in these kinds of cases, it is inevitable that the judges' values will impact the case.

One recent example of the judges' values appearing in their decision is found in cases decıding whether to award custody of children to lesbian or gay parents. Two such cases involving similar facts but sharply contrastıng opinions demonstrate how judges draw upon their own values to resolve difficult questions. Both cases involved attempts by fathers of young children to obtain custody from lesbian mothers due to "changed circumstances." Both involved mothers who had lived with other women, and children whom the trial court had found adversely affected by the mother's homosexual conduct. In both cases, the trial court had ordered custody changed to the father based on the best interest of the child. One appellate court upheld the decision, the other reversed.

Of course, as in any such case, the facts were not identical. What is important here, however, is how the two appellate courts viewed some of the same key facts totally differently, contributing to the opposite results. The Arkansas court, applying the "best interest of the child" standard, found no error in the trial court's consideration of "the effect of Mrs. Larson's lifestyle and the attendant publicity on the children." It found the trial court's 
Paul L. Biderman, Esq.

concern especially appropriate in view of the concern of the older child, Mikey, over the effect of his mother's conduct on his younger sister. ${ }^{\text {D }}$ No other evidence was cited by the appellate court to support any rational basis for the trial court's concern in this regard. The court noted, among several changes in circumstances, that the mother and her female lover had engaged in sexual relations while the children were at home. It found no error in the trial court's finding that the mother had engaged in "deviant sexual activity" -- for which it cited as evidence only the female lover's testimony that they had sexual relations.

The New Jersey court (with one dissent) viewed very similar findings by the trial court very differently. It noted the failure of the trial court to demonstrate a relationship between the mother's sexual identity or conduct and the welfare of her children, even though the older child had developed emotional problems. "The Court found a heavy burden on those who would attempt to show that a mother is guilty of gross sexual misconduct to the detriment of her children."

But the court saved its most eloquent statement for last. Addressing the issue of embarrassment to the children caused by their mother's variant sexual orientation -- a factor cited by the Arkansas court in upholding the removal of custody from the lesbian mother -the court stated that, "[o]f overriding importance is that within the context of a loving and supportive relationship there is no reason to think that the girls will be unable to manage whatever anxieties may flow from the community's disapproval of their mother."73 As for the possible adverse impacts on the children's welfare arising from community intolerance, the court's rejoinder is well worth reproducing in full:

"It is just as reasonable to expect that they will emerge better equipped to search out their own standards of right and wrong, better able to perceive that the majority is not always correct in its moral judgments, and better able to understand the importance of conforming their beliefs to the requirements of reason and tested knowledge, not the con- straints of currently popular sentıment or prejudice.

"Takıng the children from defendant [the mother] can be done only at the cost of sacrificing those very qualities they will find most sustaining in meeting the challenges inevitably ahead. Instead of forbearance and feelings of protectiveness, it will foster in them a sense of shame for their mother. Instead of courage and the precept that people of integrity do not shrink from bigots, it counsels the easy option of shirking difficult problems and following the course of expedience. Lastly, it dimunishes their regard for the rule of human behavior, everywhere accepted, that we do not forsake those to whom we are indebted for love and nurture merely because they are held in low esteem by others."74

The contrasting opinions in these two cases solidly illustrate two points. The first is that the different sets of judges viewed not only these facts, but the world quite differently; and those value differences were vital to the opposing decisions they rendered. Given the complex of facts involved in each case and the vagueness of the standard at issue, neither court could be declared to be objectively wrong in their decision by any higher authority (a higher court might have reversed either decision and settled the issue, but the law could permit that higher court to go either way). But the second point is even more important: that the judges in both cases, faced with a general standard (best interest of the child) permittıng them broad judicial discretion, relied very much on their own values, not necessarily those of their community, in rendering their decision. Indeed, the New Jersey court specifically endorsed the value of opposing a hostile community when its standards derive from bigotry. The fact that they relied on their own values was not improper under the law. How each court chose to apply its own values, however, may have been improper, a subject we will explore below.

A final example should demonstrate how judges' personal values enter appellate decisions on policy questions. The issue is whether school districts that distribute condoms to high 
school students without parentai consent violate the constitutionally protected rights of parents to rause their children as they see fit. ${ }^{\text {'s }}$ Although the court that struck down the program also relied on a state statute requiring parental consent for any health service, nevertheless the courts both ruled on the constitutional issue, with opposite results.

The Alfonso court found that public schools could not constitutionally distribute condoms to students under a program that did not require parental consent, unless the school permitted parents to opt their children out of the program. Absent parental consent, the court found, free condom distribution by public schools interfered with the constitutionally protected rights of the parents to "influence and guide the sexual activity of their children without State interference." 76 The court acknowledged that, to strike down the school district polıcy, it would have to find some act of compulsion by the state displacing the parents' discretion in rassing their children. It found that compulsion in the fact that the program, without parental involvement, "offers the means for students to engage in sexual activity at a lower risk of pregnancy and contracting sexually transmitted diseases." $n$ Since the parents are required to send their children to public school (they could not afford private schools), and the program created in the schools "an environment where they had unrestricted access to free contraceptives," there was compulsion enough." Nor did the court find a compelling state interest in the prevention of the spread of AIDS among teenagers in New York (despite statistics it cited concerning the alarming rate of adolescent AIDS there), because alternate means existed for students to obtain condoms.

The Supreme Judicial Court of Massachusetts did not see things this way. Distınguishing Alfonso primarily for its reliance on the New York statute requiring parental consent for student health procedures, the case nonetheless rejected the New York court's determination that constitutionally protected parental rights were violated by the program. The Curtis court focussed on the absence of compulsion by the district's policy. Even though the parents would not have been consulted or notıfied about their children seeking contraceptives, the Massachusetts court found that participation by the students was voluntary Just because student attendance at school is compulsory does not make participation in the condom distribution program compulsory Hence no opt-out or parental notification policy was required for the program to pass constıtutional muster.

Assuming that both interpretations of the constitutional caselaw are viable, what made the difference between these two decisions? Was one court right and one wrong in advancing or impeding the law's evolution in this field, under Dworkın's "integrity in law" analysis? Did each court apply the standards of their own respective communities, as Greenawalt might find? Were the judges seeking to advance a personal agenda, as a legal realist might have assumed, or uphold the interests of powerful political groups, as critıcal legal studies theorists might claim?

My belief is that the judges on the two courts weighed the values inherent in the alternative possible outcomes in the case on the scales of their own value systems. They then considered the legal questions through the filter of their value perspectives. Whether or not the policy of the school districts involved compulsion was a matter on which reasonable minds could, and did, differ. For the New York court, the preservation of parental control over adolescent sexual behavior was a paramount value. From that perspective, the condom distribution policy was compulsory, because parental insistence on sexual abstınence could be effectively negated by the policy of a school to which the parents were legally compelled to send their children. For the Massachusetts court, the interest of the school district in protecting its students against pregnancy and sexually transmitted disease through easily accessible condom distribution was the higher value. From that viewpoint, the policy was voluntary, since no children were compelled to participate in the program. Thus the judges' differing values actually produced different interpretations of the legal question of whether or not the element of compulsion was presented by these facts.

I believe that these examples have shown 
that judges' values play a significant role in judicial decisions that serve to develop the law. Moreover, I hope that I have begun to show that such reliance on values in these decisions is expected and inevitable, since there simply is no objective viewpoint from which judges -- or any other human beings -- can observe legal issues with complete impartiality and detachment. Indeed, I doubt we would even want them to.

Having looked at the work of the appellate courts, I will now consider whether judges' values play a role in the daily, if less publicized, work of the trial courts.

\section{B. Values in the Daily Case}

Although attention is understandably drawn to the landmark appellate opinion that redirects the course of an entire body of law, the day-today work of the trial courts is where the vast majority of people come in contact with the judicial system. In theory, the higher courts establish the broad standards of the law and the trial judges simply ensure their application to real cases. Yet in reality, judicial discretion exists in numerous situations at the trial level, and is treated with great deference by the appellate courts. This discretion can be and is used to determine which facts are of primary importance in an individual case. The resolution of factual issues in tum determine which rules of law govern the case and how the approprate rules are to be applied. In a very real sense, the most important measure of the effectiveness and justness of a judicial system lies in its treatment of the particular, rather than in the evolution of its approach to the general.

To illustrate this point, I will pose several ordinary. hypothetical cases and show how two judges with different values can make very different rulings, both well within their range of authority. Of course, this exercise will come as no surprise to the judge who has been torn between altematuve rulings on a case and knows she could easily have decided the other way; nor to the attorney who rued the assignment of his case to the "worst" judge on the court (for that lawyer's case, anyway.) Still, it is useful to analyze how such differences in outcomes can occur within the same legal framework.

Hypothetical \#1 Defendant is convicted of battering his wife in their home in front of their two young children. The victim has asked to withdraw her complaint and has testufied only grudgingly, but the prosecution has proceeded because of the district attorneys "no drop" policy in domestic violence cases. The defendant has a good-paying $\mathrm{ob}$ and is in all other respects a model citizen, but has shown little sign of remorse in testumony or at sentencing. Defendant has, however, promised not to strike his wife again. At trial, the wife has admitted on cross-examination to having "provoked" her husband to the anger that led to his hiting her. The sentencing report shows that police have been called to the home because of loud anguments on several occasions and had found indications of previous beatings by the defendant. The judge now must pass sentence, which can range from anywhere between probation and a year's imprisonment.

Judge A places a high value on the importance of intact families. A is concerned that if defendant is jailed, he may leave the family in frustration and humiliation. A also sees defendant as a good provider for his family and fears that the family will suffer economically if defendant loses his job while in jail. $A$ is concerned that defendant may batter his wife agan, but after all the victım has asked that the matter be dropped and this is a first conviction. $A$ decides to place defendant on unsupervised probation and to recommend anger management counseling.

Judge B values very highly the dignity and self-respect of each human being. From B's perspective, defendant's criminal conduct threatens not only his wife's physical wellbeıng, but also her emotional state. His apparent pattern of beating her is designed to intımıdate her into submission, and its success is demonstrated by her reluctance to prosecute or testify against him. B views this as a critical time for the law to assert itself in behalf of the victım and drive home to an oblivious defendant the unacceptability of his conduct. $B$ sentences defendant to ninety days in jail, with sixty suspended provided there are no further incidents.

1996 / Juvenile \& Family Court Journal 75 
Both judges have acted, on identical fact scenarios, within their lawful authority. Both judges have advanced legitımate purposes of the law and have reflected values that are shared within their communities. Yet the two judges have delivered dramatically different outcomes. The difference lies in the different values the two judges brought to their decision-making responsibility and through which they weighed the various facts presented. And, by allowing a fairly broad range of sentencing options, the legal system has not only tolerated the judges drawing upon their own values to make their decisions; the system has necessitated that they do so. A second hypothetical will demonstrate that such issues are not limited to "hot button" issues of the day.

Hypothetical \#2. A jury finds that a defendant car dealer commulted a fraud against plainiff buyer. The dealer had represented at the time of sale that the car had recerved a few thousand miles use as a demonstrator, one that the sales staff drives around to provide exposure for the new model. In fact, the buyer learned by accident that the car had been previously sold and returned by a customer who was dissansfied with its performance afier several hundred miles of driving. Some scratches had been touched up by the dealer afier 11 had been retumed, but no other damage had occurred. The jury's vendict awards the plaintiffa full refund plus ten thousand dollars as actual damages and two hundred thousand dollars in punitive damages. No state law limits punitive damage awards. The defendant moves to set aside the punitive damages award as excessive.

Judge $C$ believes that integnity in the marketplace is at the heart of the capitalist system and that preserving it is the highest duty of the courts in commercial cases. The jury's large award sends a message to this dealership and other merchants against misrepresenting the quality of their goods, both to protect the buying public and to protect honest vendors against unfair competition. $C$ therefore upholds the award.

Judge D views small business as the backbone of the economy. $D$ understands the difficulties confrontıng small businesses that some- tımes lead them to exaggerate to pay the rent. D knows that managers cannot observe every transaction made by their employees and that pressures to meet sales quotas can cause some overzealous clams. In this case, the buyer's actual damages were more than compensated for by the jury's award and the punitive damages were totally disproportionate to the actual injury. $D$ therefore sets aside all but ten thousand dollars of the punitive damages award.

Here again is an example of the law vesting a broad range of discretion in its judicial officers. Each judge in this hypothetical has acted within that range of discretion. Both judges could point to a substantial body of community sentıment upholding their respective values: indeed, some segments of the community, like the defendant dealership's competitors, might adhere to both viewpoints simultaneously. Ultimately, the choice is left to the sound discretion of the trial judge -- and that discretion can only be exercised in the context of the judge's values.

\section{Toward Gutdelines for the Integration of Values in Judging}

One can visualize numerous such examples in almost every field of judicial jurisdiction: grantıng of injunctions, domestic relations decisions, juvenile court proceedings, parental rights termınations, contract law, landlord-tenant disputes, and bail bond hearings, to name just a few. To say that these cases may all entail, at least some of the time, applications of judicial values, is not to suggest that legal standards are nonexistent and judges can rule any way they want. As Burton has pointed out, ${ }^{79}$ the law defines those arguments and factors that a judge may or may not consider; the job of the judge is to identify those authorized considerations and then to weigh among them. Sometimes, analysis of the acceptable factors leaves the judge with only one allowable alternative - for example, if the plaintıff in hypothetical \#2 had admitted that defendant dealer's misrepresentation had been a mistake and the jury's punitive damage award had not been authorized by the court's instructions. Under those facts, the judges would not have had the occa- 
sion to consult their own value systems because the law would have left no discretion to let the award stand. But pretrial motion practice and the expense and delay of the legal process filter out many cases where the law is so clear. In those cases where the law is not so clear, or where the law clearly vests discretion in the judge, the weighing process among the range of acceptable choices inevitably invokes the judge's own value system.

As noted earlier, the hardest work in this field lies in the development of guidelines that will help judges to apply their values appropriately, confidently and openly. I will now suggest some guidelines that may offer some impetus to this inquiry. These are primarily adapted from Morawetz, supra, Part I (F).

\section{Suggested Guidelines for the Application of Values in Decision-Making.}

1 Values applied in a case should be consistent with applicable legal rules Judges should not decide cases on the basis of values that are contradictory to, or inhibit the policy underlyıng, applicable rules of law. That is not to say that a court may not overrule outdated, unconstitutional or invalid legal doctrines when recognized legal grounds exist to do so. But a judge's personal beliefs may not override his duty to uphold the law in the absence of such grounds. For example, a judge's belief that insurance companies should pay damages to automobile accident victıms regardless of who was at fault cannot overnde a valid clause in the insurance contract that awards payment only if the insured was at fault.

2. A judge's values should be factually supported. This guideline refers both to the facts in evidence and the facts of the real world. Just as the values drawn upon must be consistent with applicable rules of law, so too must they conform to factual reality. To take an improbable example, a judge who denied bail to a crimınal defendant in a burglary case on the sole ground that the defendant was a welfare recipient and all welfare recipients are transients would be acting out of sheer ignorance, not a defensible value system.
3. A judge's actions must be rationally based. Even if judge relies on true facts and legitımate values, the resultıng actions taken must be rationally derived from those facts and values. In the domestic violence hypothetical above (hypothetical \#1), even if Judge A's value system and vew of the facts could rationally support probation for the defendant, they could not rationally support imprisonment of the victım to prevent her from provoking his ire.

4. The judge may not rely on personal values that undermine more fundamental legal and societal values. An example here might be a judge who so valued the protection of society agaunst criminal conduct that she handed down the maximum allowable sentences to every convicted person, regardless of any mitigating factors. Fundamental values of justice would be damaged by such a mechanically harsh policy, even if the sentences were within the law and consonant with the judge's honest personal value system.

5 Judges may not rely on values that are rooted in prejudice, self-interest, or dishonesty. Certain precepts are so fundamental to our democratic system as to override any attempt to impose conflicting values. Thus, a divorce court judge who denied custody to a Hindu parent on the grounds that it is in the best interest of the child to be raised in a Christian household could not be sustained regardless of the sincerity of his values. Similarly, the judge whose values compelled her always to rule for the laborer in workers' compensation cases could not justify her conduct by citing her strong workıng class values.

6. A judge relying on values to decide a case should share publicly the values relied on. A judge who bases a legutimately discretionary decision on her own values should be ready and willing to share that basis publicly with the litigants and anyone else who is interested. If the judge feels that the basis for the decision must remain secret, it becomes suspect. Any value that is strong enough to impact on the outcome of a lawsuit or prosecution should be strong enough to withstand public revelation and scrutiny. Furthermore, unless the judge can articulate clearly and publicly her reasons for her decision, including the values she has 
invoked, even the judge herself should doubt whether she should be confident in the ruling.

7 When relying on his values, a judge should consider the direct and indirect conse. quences of his ruling. Such consequences may include not only the consequences to the parties in the case, but also to other litıgants and people who may modify their behavior to avoid litigation.

These proposed guidelines, to which more could undoubtedly be added, are more limiting in nature than they are directive. That is because judges should have considerable flexibility in applying those relevant values that are consistent with the governing rules of law and established facts of the case. So long as the judge's values do not enter prohibited territory, it should be presumed that the law contemplates that judges will draw upon all values relevant to the resolution of indeterminate cases.

We have seen that judges must at some point in many of their decisions consider their personal values. We have suggested guidelines that will support their confident reference to those values. We now tum to the final consideration of this article: how should judges prepare themselves to exercise their values as judiciously as possible?

\section{Preparing to Exercise Values in Judicıal Proceedings}

If judges are expected to draw upon their values in cases where they have been invested with discretion by accident or design, how then are they to prepare themselves for that responsibility and continue to develop in their ability to exercise it? Law school education focuses more on conveying the structure and process of the law than on explonng the broader range of values possessed by the student or permeating our culture. Such exploration might allow judges the opportunity to test their philosophies and beliefs against those advanced by other scholars and colleagues. But the mission of Amencan law schools is to train lawyers, not judges, and the lawyer's avocation is marked more by vigorous advocacy than by the exploration of values interposed during the judicial process. If law school is not where judges are trained in the values they will apply, then where do they get that training?

The answer is both comforting and alarming: judges receive their values training from the same sources as everyone else. Values are inculcated at home, in neighborhoods, from peer groups, in school, from family, from our culture and religious institutions, from media and books. Values are the aggregation of our varied experiences, beginning with our attainment of consciousness of the status and stigma of our first adult caretakers, right through the decline of our energies as we approach death. They are born of the experiences we have and the things we learn, and are constantly tested and reshaped by them.

"Values are extensions of belief systems that are personalized, over a period of tume for each individual. They are terminal or instrumental. They are affected by people, experience, circumstances and age. They can be cumulative and strengthened or weakened by tume."

\section{A. Natural Selection. The Haines Solution}

In addressing how judges may prepare and mantaun their abilities to exercise values in their work, we should begin by examining an approach proposed at the dawn of the legal realists movement. Charles G. Haines observed early in this century that judges, and particularly the Supreme Court Justices who determine constitutional issues, are influenced by their personality, education, associations, and individual views. Hannes suggests that "[m]ore attention should be given to the personal, political, and economic affiliations of those selected for the federal judiciary.

This is certainly a valid suggestion, and not only for the federal judiciary. The judiciary maintauns no army or police force: voluntary compliance with judicial orders is vital to its effectuveness. Such compliance is unlikely in the absence of credibility of the judicial system and its members, and, as with any democratic institution, credibility depends on a perception 
of inclusiveness: no group within a democratıc society that identifies itself as a group should perceive itself as systematically excluded from an institution that stands for the power of the state. Thus it is important for the faces of the judiciary to be diverse and representative, and to reflect the diversity of values of the larger society.

Acknowledging some merit in Haines' suggestion, it clearly does not 80 far enough. Regardless of the backgrounds and value systems of judges when they assume the bench, it must be assumed that, like everyone else, their values change and develop over time. Judges are inevitably and constantly confronted with issues they have never before encountered and on which they have never previously had to articulate a public, reasoned and authoritative stand with such powerful consequences. Having to exercise their values in such situations, judges are compelled as are few other people to examine and question those values and discard or modify those that do not survive these constant tests. Selecting judges on the basis of their representation of specific social or political philosophies could discourage such personal growth and their ability to adapt to new situations and knowledge. Moreover, as noted by Wells, the backgrounds of litıgants who appear before judges are so diverse that the system is not required to supply a "psychosocial twin" for every litigant so that his perspectuve can be fully understood. ${ }^{12}$

It is therefore not enough to select judges based on personal backgrounds that may influence their decisions in the future. Judicial systems must also provide constant opportunities for judges to reevaluate their value assumptions in constructive, informative and safe settıngs. Judicial education programs provide the ideal vehicle for this endeavor.

\section{B. Exploring Values through Judicial Education}

Most states and the federal judiciary now have judicial education programs for new and sitting judges. The state programs vary considerably in scope and resources. Continual exchanges of information and ideas among judi- cial educators ${ }^{13}$ and the inception of joint, mult1state activities in several regions have, however, caused the emergence of significant programming trends, many of which support the development of judicial values. I will conclude this article by suggesting some criteria for educational programming appropriate for this work.

Judicial educators -- by which I include the program administrators, planners (including judges), and instructors -- should continually examine and identify value issues arising in the work of judges. Just as judges constantly seek and are provided education in developments in the laws they apply in their courts, so too must they recerve education in the values they apply in their decisions. Educators should ensure that judges are offered facts, established and emerging theory, and opportunities for discussion and educational activity concerning such issues. And they should provide this material in effective and meaningful forms.

Examples of value-based educational programming include training in cultural diversity, family dynamics, child development, mental illness, racial and sexual politics, and the culture of poverty, among many other issues. The good news is that this is no news to many state judicial educators who have initiated a host of such programs already. The National Association of State Judicial Educators (NASJE) has published standards that advocate the inclusion of such subjects as cultural awareness, elimination of bias or prejudice, contemporary social issues and law and the humanitıes withın state judicial education curricula. ${ }^{4}$ The not-so-good news is that such programs are still received with mixed reactions by some judges. The purpose of this article is not to preach to the converted, but to offer judicial educators a framework within which to plan their programs, and to demonstrate to their audiences the necessity for the values-based programs they are already undertaking to introduce.

I suggest several guidelines, compiled from the reported experiences of various judicial educators, for the presentation of value-based educational programming. These guidelines are intended to help educators maximize the 
effectiveness and minimize resistance to these programs, at least until they become as routine as presentations to judges on evidence and criminal law updates.

\section{Guldelinesfor Values-Based Educational Programs}

1 Demonstrate the need for the program. Judges attending a program should be given information demonstrating its usefulness to their work. This can be done by reporting the resuits of needs assessment surveys that show a demand for this kind of programming. In addition, judges should be offered at the outset an explanation of the context in which they will be able to use the information they will be presented. For example, a program on domestuc violence can be presented as an aide to effectıve strategies for sentencing offenders and issuing protective orders.

2. Clarify the learning objectives. Always a good idea, the clear identification of learning objectives is particularly crucial in presenting values-based educational programs. If presented properly, the learning objectives will advise the judges what they will be able to do as a result of attending the session. Stated learning objectıves will help keep some judges focussed on the context in which they are being presented with material that they may find unpleasant or unfamiliar."

3. Prepare the presentation thoroughly. As any trial lawyer knows, a single misstatement by a witness, particularly an expert, can undermine the credibility of days of testımony. Judges are trained to be skeptucs and most do it well. Values-based material may be greeted with particular skepticism and should be therefore be presented with sound factual support.

4. Present the material in an open manner. Since ideas presented in these kinds of programs are likely to challenge long established values, a confrontational approach will inevtably fail. Preaching, challenging or patronizIng styles will set back any effort to induce judges to reconsider values they already hold. The presenter who undertakes an educational program with a mission of converting the judge to his viewpoint will usually be disappointed. The objective of the presentation should be only to present the judges with information, concepts, and an invitation to reconsider their premises and assumptions in a new light. The presenter may have to accept the fact that a position in between his own and the judge's may be the optimal one.

5. Offer practucal, attainable solutions. It may be exciting to present an educational program on cuttıng edge programs for juvenile or drug intervention, but if the judge hasn't a remote chance of implementing them within her term of office the outcome could be frustration. Ideas presented should be within the judges' grasp.

6. Present visceral material in a visceral format. Much of the values-based material that has been discussed involves "connected," emotional content as much as or more than it does "separate," intellectual content. Judges often need the "ability to empathıze and connect with the views of the various parties." No amount of legal analysis will generate a correct answer to most child custody determinatıons; the judge needs to determine from limited evidence such factors as the degree of caring and skill each parent would apply to the rearing of children. To make such a determination, the judge needs to be able to extrapolate from isolated examples of conduct and testimony presented in a trial to the kind of overall parent a father or mother would make.

Lectures can shed light on such determinatıons, but even more valuable may be demonstration during educational programs of such techniques as theater and role-playing, wherein the judge actually feels the emotions of a parent in a custody dispute. Such skills can then be adapted (mentally, that is) into the courtroom. Another technique gaining considerable popularity is the "law and literature" seminar. Such programs reportedly improve judges' understandings of different cultures and perspectives and expand creativity in applying values to legal proceedings."

7 Reinforcé value-based educanonal experiences through active use of the material. Judges should be given opportunities to work with the material they have been presented. 
Since the material may be unfamiliar and may challenge long-held beliefs, using it gives the judge a chance to own it and work through misconceptions or hesitancy. For example, a program on alternative sentencing could present a small group of judges with several hypothet1cal sentencing problems that suggest various dispositions.

8. Enlist the support of peer groups. Judges will be most open to ideas for reexamıning their own perspectuves if those ideas come from respected colleagues. Integration of such peers into educational programming to report on their own experiences with new ideas will be most likely to overcome resistance to reevaluation of values used on the bench. Also, opportunities for discussion among Judges can encourage candid airing of misgivings about different ideas.

9 Respect other value systems. Above all, judicial educators, whether judges, administrators or instructors, should never forget their limited role within the judicial system. It is the judge who has been empowered to dispense justıce, not the educator. No matter how deeply we may be convinced of our own beliefs, Judges' values are derived in part from the community they identify with and serve. Values education for judges is not a remedial course: it is intended to offer for the judge's consideration information about developing findings and concepts in a constantly changing world. The judge is always entitled to reject those offerings so long as they are not legal requirements.

This point bears emphasis. The purpose of this article has not been to suggest that judges' values are deficient or outdated. Rather, I have tried to show that values represent an inevitable and integral part of the judicial process and that the presentation to judges of information and thought that may develop their values is as essential to their education as is the presentation of educational programming on legal subjects.

\section{Conclusion}

Some would still cling to the concept that the ideal judge is a logic-bound Vulcan, like Mr. Spock on the Star Trek series. Yet our legal system expects and needs judges to call upon their other attributes as well. mercy, inturtiveness, insight, personal understanding. Much of what a judge is expected to do requires the exercise of the judge's personal values. That reality should not be resisted or concealed. Rather, the legal system should recognize and honor that fact; define its limits and its scope; and then strengthen the skills that it calls upon. Just as a judge would invariably be open to education about developments in the law, so too must judges be receptive to the developments in the material that forms and reinforces their values. Just as a judge would never knowingly apply outdated or rejected doctrines of law, so too should a judge constantly be open to testing and reconsidering the values governing judicial decisions. The challenge for judicial educators is to identify the areas where values are operative, recognize where new information is needed, and present that new information in ways that will constructıvely address the judges' needs for reaffirmation and development.

I conclude with a quotation from Calamandrei's Eulogy of Judges.

"The decision is thought of as the result of a purely logical process, coldly considered in the abstract, bound together by an inexorable chain of premises and conclusions. But in reality under all the trappings of magistracy the judges are only human beings through whom invisible magnetic forces are playing, forces which attract and repel them, humanly and illogically, toward certain conclusions and away from others. How can an opinion faithfully reproduce the judge's motıves if it fails to take into consideration the subterranean meanderıngs of these sentimental currents from whose influence even the most austere judge is never free?":

Author's Address:

Paul Biderman, J.D

The Institute of Public Law

University of New Mexico School of Law

1117 Stanford, N.E.

Albuquerque, NM 87131 


\section{Notes}

'Quoted from Mnx Lerner, The Mind and Faith of Jystice Holmes, 79-80 (Little, Brown 1943). 1881).

2Olive Wendell Holmes, The Common Low, 1 (Little, Brown,

'Oliver Wendell Holmes, The Path of the Law. Collected

Legal Papers, 167181 Harcourt, Brace, 1920).

Id.

'Id. at 184.

'See, e. 8., Lochnerv. New Yont. 198 US 45 (1905).

Zemet, at xoxii - xouv.

TH.L.A. Hart, "Positıvism and the Separation of Law and Morals," 71 Harv L Rev 593 (1958).

Jd. at 629.

${ }^{10}$ H.L.A. Hart, Essogys in Junsprudence and Philosophy, 6

(Oxford University Press, 1983).

"ld. at 7.

12Roger Traynor, "Ressoning un a Circle of Law," $56 \mathrm{VaL}$

Rev 739, 749 (1970).

"Jerome Frank, "The Cull of the Robe," Satunday Review,

1213 (October 13, 1940).

"Jerome Frank, "What Courts Do in Fact," 261llL Rev 645,

$656(1932)$.

is/d. at 653 .

"Boiley Kurlin and Jeffrey W Stempel, Foundations of

Low. 156 (West, 1994).

"Roscoe Pound, "Mechanacal Junsprudence," 8 Colum $L$

$\operatorname{Rer} 605$ (1908).

18Id. at 609610.

'Benjamin Candozo, The Noture of the Judicial Process, 66

(Yale Unvversity Preas, 1921).

"Benjamin Cardozo, The Paradaxes of Legal Science, is

Columbia University Press, 1928).

"Id. at Ss 56.

nloyd, The ldea of Low, 262 - 3 (Pengun 1964).

"Id. at 212213.

uHerbert Wechsler, "Toward Neutral Pnnciples of Constututuonal Law," 73 Harv L Rev 1 (1959)

(1954)

${ }^{23}$ Brown v. Boand of Education of Topeka, 347 US 483

Wechsler at 19 ,

nId. 1986).

Ronald Dwortan, Law s Empire, Chapler 7 Bellonsp Press,

Id. at 225.

\%Id. at 134.

"Id. at 255.

12Ronald Dwortin. "The Moral Readine of the Constitu-

tuon, New York Revien of Books, 46, 48 (Murch 21, 1996)

"Dworkin, Low s Empir, at 378.

YI. at 249 [emphans edded].

ss.d. at 257 .

"Dwortan, "The Mord Reading of the Constitution," at 48.

"Comelius F. Mupty, "Dwortan on Judicual Discretuan: A

Critucal Andysis, " 21 UC Dovis L Rev 767, 781 (1988).

Kent Greenewalt, Low and Objectivity, 34 (Oxford Unversity Prese, 1992).

old. at 47

"If judges properly rely on therr own maral assessments, as contrasted inth those reflected in law or accepted by the community, it is generally only when the latter sources fail to give clear guidnnce or when the difference between those sources and the judges' assessments is margand." Id. at 62.

"Id. at 145.

"He actually presents this point to explore the problem of insertang feminine stundurds of reasonableness into a maxculine dominated system of law, but the analysis bas broader implications.

'Jd. at 166.

H. at 216.

4J. at 184 et seq.

82 Juvenile \& Family Court Journal / 1996
Id. al 226.

"Harny Edwards, "The Judicial Function and the Elusive Goal of Pruncipled Decisionmakang " 1991 Wis LRev 837 (1991). 4 Id. at 861 .

"Mark Tushnet, "Critucal Legal Studies: An Introductson to its Ongins and Underpinnags, $36 \mathrm{~J}$ Legal Educ 505, 508 (1986).

"Divid M. Trubek, "Where the Action is: Cntucal Legal

Studies and Empunc1sm," 36 Stan L Rev S75, 577-8 (1984)

"Thomas Morawet, The Philosophy of Low: An Introduc.

tion. (McMillam 1980).

s'see discussion id. at 34.

"Steven J. Burton, Judging in Good Faith, 28 (Cambndge

UPress, 1992).

sld. at 11 .

"Id. at $42 \cdot 43$.

Morswetz at 75.

"Id. at 50.

"David E. Van Zandt, "An Alternatuve Theory of Practical Reason un Judicial Decisuons," 65 Tulane LRev 775, 777 (1991). "Id. at 792 - 3.

"Cathanne Pierce Wells, "Improving One's Situstion: Some Pragmatic Reflections on the Art of Judging," 49 Washington and Lee L Rev 323 (1992).

"Id. at 330 .

-Burton at 60.

I would contend that such movements, by emphasizing a particular aspect of the umplications of judicual decisjons such as the balance among economuc interests, requue judicial value judgments. A judge who elects to decide a controversy on the basis of relative economic umpacts to the parties rather than on some other grounds does so pursuant to a value systetn that emphanzes protection of econcenic voter eats as a promary purpose of the judicial system. Thus would be true even if the actur process of weighing the relative economic interests could somebow be made objectuve.

"Brown v. Board of Education of Topeka. 347 US 483 (1954).

oplessy v. Ferzuson, 163 US 537 (1896).

*347 US at 495.

"Two of the state school systems whose segregation policies were struck down in Brown were those of Delaware and Kansas.

- Larson v. Larson, 50 Ark App 158, 902 SW2d 254 (Ark App, Div L, 1995) M.P v. S.P., 169 NJ Super 425, 404 A2d 1256, 100 ALR 3d 604 (1979).

Larson, 902 SW2d at 256.

rJd. The opinion does not state whether Mikey had been qualified as an expert witness on this point.

"M.P. 404 A2d at 1259.

njd.

IId. at 1262.

"Id. at 1263,

"Alfonso v. Fermandex, 195 AD2d 46, 606 NYS2d 259 (Sup Ct, App Div, 2d Dept, 1993); mot. for iv. to appl. dism'd, 614 NYS2d 388 (1994): and Currtis v. School Committee of Falmowth, 420 Mass 749, 652 NE2d 580 (1995). Both courts considered and regected a first amendment claum of state interference with the pareats' free exereise of religron.

Alfonso. 606 NYS2d at 266.

rid.

r/d.

See supra, Part $L$

- Natuonal Council of Juvenile and Family Court Judges, The Crucial Nature of Volues and Atritudes in Judicial DecissonMakang. Particupant Notebook, 11 (1991).

"Haines, "General Observations os the Effects of Personal, Political and Economic Influences in the Decisions of Judges,"

17 III L Rev 96, 113 (1922).

Wellsat 337.

- Particularly through the National Association of Judicial Educators and the Judicual Educatuon Reference, Informatuca and Technucal Transfer Project (JERTT). 
Wational Association of State Judicial Educators, Prncuples and Standards of Continuing Judicial Edwcation, is - 16 (NASJE, 1991).

Id. at 17.

w Wells at 332. For a more detailed discussion of the applications of connected and separate knowng concepts to the judic1al context, see Charles S, Claxton and Patncia H. Murrell, Education for Development: Pnnciples and Proctices in Judlcual Education: JERITT Monogroph Three, Chapter III (Judicul on Reference, Informatuon and Technical Transfer Project, Educetuon, 1995).

"Ruchard Delgado and Jean Stefancic, Norms and Narreuves: Can Judges Avord Senous Moral Errorn", 69 Tx $L R$ r 1929 (1991). For more discussion on the applicatson and advantages of "experientual learning" techniques to judicul education programming, see Claxton and Murell, Chaptel.

Piero Calamandre1, Eulogy of Judges, Transl. J.C. Adams and C. Abbott Phillips, Jr., 83 (ALI-ABA ed. 1992). 